\title{
Non-communicable diseases among low income adults in rural coastal communities in Eastern Sabah, Malaysia
}

\author{
Hazriani Harris ${ }^{\dagger}$, Yasmin B. H. Ooi ${ }^{*}$, Jau-Shya Lee and Patricia Matanjun
}

\begin{abstract}
Background: Rural coastal communities in Sabah are still overly represented in the hardcore poor economic status. The aim of this study was to determine the prevalence of hypertension, diabetes mellitus and hypercholesterolemia among adults, in relation to economic status.

Methods: A cross-sectional study using stratified random sampling was conducted in seven coastal villages in Semporna, Sabah: Kabogan Laut, Salimbangun, Pekalangan, Pokas, Tampi-Tampi Timbayan, Sum Sum and Selinggit. Socio-demographic data were obtained via interviewer administered questionnaires in Sabah Malay creole. Anthropometric measurements, blood pressure, fasting blood glucose and blood lipids were obtained.

Results: A total of 330 adults (133 males, 197 females) completed the study. Mean age was $43.7 \pm 15.8$ years. Most participants (87\%) were living below the Poverty Line Income. Median per capita household income was RM83.33/ month $(\approx$ USD20/month). The number of newly diagnosed cases of hypercholesterolemia was $40.6 \%$, diabetes mellitus was 5.8\%, and hypertension was 24.5\%. Adults from the hardcore poor economic status (household income $\leq$ RM760/ month ( $\approx$ USD183/month) were the most represented in those who did not have a blood pressure, blood sugar and blood lipids check in the 12 months preceding the study $\left(X^{2}, p<0.01\right)$. Adults from hardcore poor economic status were also the most represented in undiagnosed hypertension and uncontrolled blood pressure among those diagnosed $\left(X^{2}\right.$, $p=0.013$ ). Among diabetics from the hardcore poor group, the undiagnosed fasting blood glucose was $11.2 \pm 4.5$ compared to $5.1 \pm 0.6 \mathrm{mmol} / \mathrm{L}$ for diagnosed diabetics $(p<0.001)$. Among hypercholesterolemics from the hardcore poor group, total cholesterol and LDL cholesterol values were significantly higher in the undiagnosed group compared to the diagnosed group $(p<0.001)$.

Conclusion: Many people in this rural coastal community were unaware that they had high cholesterol level (40.6\%) and elevated blood pressure (24.5\%). Routine health check is not common among low income adults in rural coastal communities in Semporna. The findings suggest public health initiatives should emphasize access to and the necessity of routine health checks for those aged 40 years.
\end{abstract}

Keywords: Non-communicable diseases, Rural, Coastal

\footnotetext{
* Correspondence: yasmin@ums.edu.my

${ }^{+}$Hazriani Harris and Yasmin B.H. Ooi are contributed equally to this work

Faculty of Food Science and Nutrition, Universiti Malaysia Sabah, Jalan UMS,

88400 Kota Kinabalu, Sabah, Malaysia
}

(c) The Author(s). 2019 Open Access This article is distributed under the terms of the Creative Commons Attribution 4.0 International License (http://creativecommons.org/licenses/by/4.0/), which permits unrestricted use, distribution, and reproduction in any medium, provided you give appropriate credit to the original author(s) and the source, provide a link to the Creative Commons license, and indicate if changes were made. The Creative Commons Public Domain Dedication waiver (http://creativecommons.org/publicdomain/zero/1.0/) applies to the data made available in this article, unless otherwise stated. 


\section{Background}

The current body of research into rural health in Malaysia showed $41.3 \%$ of indigenous adults in Sabah [1], 33.6\% of adults in rural Kedah [2], and $29.8 \%$ of adults in rural Penang [3] had hypertension. The nationally representative National Health and Morbidity Survey 2015 showed overall hypertension among adults aged 18 years and older was $33.5 \%$ (95\%CI: $31.6-35.4$ ) in rural areas compared to $29.3 \%$ in urban areas (95\%CI: 28.2-30.4). At the national level, prevalence was higher in males (30.7, 95\%CI: 29.5-32.2) compared to females (29.7\% (95\%CI: 28.5-30.9) [4]. The REDISCOVER study investigated hypertension in urban and rural Malaysian communities from 2007 to 2011. It also reported that rural communities had higher prevalence of hypertension (51.2, 95\%CI: 49.8-52.4) compared to urban communities (44.9, 95\%CI: 43.6-46.2) [5]. In Sabah, the prevalence was reported as $26.8 \%$ (95\% CI: $23.8-30.0$ ), but the prevalence of undiagnosed hypertension was $13.9 \%$ (95\% CI: 11.8-16.3) [4]. Nationally representative studies reported that the prevalence of hypertension in Sabah had been 29.1\% (95\% CI: 26.3-32.0) from NHMS 2011 and 29.9\% (95\%CI: 28.2-31.6) from NHMS 2006 [6]. For the same reporting period, the country prevalence were $32.7 \%$ (95\% CI: 31.6-33.7) from NHMS 2011 [7] and 32.2\% (95\% CI: 31.6-32.8) from NHMS 2006 [8]. The trend was that prevalence of hypertension in the state of Sabah decreased from 2006 to 2015 and had been consistently lower than the country prevalence. At the national level, the prevalence of overall and undiagnosed hypertension were higher in lower income groups [4].

The NHMS 2015 reported that the prevalence of hypercholesterolemia was $47.7 \%$ in both rural and urban areas in the country. In Sabah, the prevalence was $40.9 \%$ (95\%CI: 36.9-45.0), and the prevalence of undiagnosed hypercholesterolemia in the state was 32.6\% (95\%CI: 28.7-36.8) [4]. This was an increase from $31.1 \%$ (95\%CI: 27.9-34.5) in Sabah from the NHMS 2011. The country wide prevalence from the NHMS 2011 was 32.7\% (95\%CI: 31.6-33.7) [7]. There was no available data from the NHMS 2006 and NHMS 1996 for the prevalence of hypercholesterolemia in Sabah [6]. Sabah had lower prevalence of hypercholesterolemia since nationally representative data were collected. Between NHMS 2011 and NHMS 2015, there was an increase in prevalence of hypercholesterolemia in Sabah. At the national level, the prevalence of overall and undiagnosed hypercholesterolemia were about the same in all income groups. In relation to gender, the prevalence were found to be significantly higher among females (52.2, 95\% CI: 50.753.7) compared to males (43.5, 95\% CI: 42.0-45.1) [4]. There was an increasing trend for all NCD risk factors. NHMS 2011 showed that at least 63\% of adult Malaysians aged $\geq 18$ years had at least one NCD risk factor, which were either overweight/obesity, high blood pressure, high blood sugar and high cholesterol [4].
The NHMS 2015 also reported that the prevalence of diabetes mellitus type II in rural Malaysia was $16.7 \%$ (95\%CI: 15.4-18.1) compared to $17.7 \%$ (95\%CI: $16.7-18.8$ ) in urban areas. In Sabah, the prevalence was $14.2 \%$ (95\%CI: 12.2-16.4), and the prevalence of undiagnosed diabetes in the state was $8.3 \%$ (95\%CI: 6.7-10.3) [4]. Over the period of available nationally representative data, the prevalence of diabetes mellitus in Malaysia had been increasing: 15.2\% (95\% CI: 14.3-16.1) in NHMS 2011 [7], $14.9 \%$ for adults aged $\geq 30$ years in NHMS 2006 and $8.3 \%$ adults aged $\geq 30$ years in NHMS 1996 [9]. For the corresponding period, the prevalence in Sabah from available data were 9\% (95\% CI: 7.2-11.3) in NHMS 2011 and 4.9\% in NHMS 2006 [6]. Sabah had lower prevalence of diabetes mellitus compared to the national prevalence, but there was an increase in prevalence from 2006 to 2015. At the national level, the prevalence of overall and undiagnosed diabetes were higher in lower income groups [4]. The most recent NHMS 2015 showed that prevalence of diabetes was higher in females $(18.3$, 95\%CI 17.2-19.4) compared to males (16.7, 95\%CI: 15.7-17.8): [4].

Nationally representative data showed that the prevalence of non-communicable diseases (NCDs) have continued to rise for the last two decades in Malaysia. In response to that, the Ministry of Health implemented the National Strategic Plan for Non-Communicable Diseases (NSP-NCD) 2010-2014 and the NCD Prevention 1 Malaysia (NCDP-1 $\mathrm{M})$ programmes. Through the NCDP-1 M, the government health services took the approach of engaging the community as a partner in prevention and promotion, such as NCD risk factor screening and intervention in the community, workplace and schools $[10,11]$. The NCDP-1 M was project based and focused on NCD risk factors. Each state determined its own NCDP-1 M project decisions. The limitations were that the quality of the projects and implementations were inconsistent, inadequate human resources and increased burden to existing services [10]. In comparison, China as a middle income country which also has an increasing NCD prevalence and burden like Malaysia, focused on comprehensive interventions in high-risk population. Like Malaysia's NCDP-1 M programme, China encouraged its local governments to develop their own strategies and measures. In contrast, Japan as a high income country has a stable NCD prevalence. Its main strategy for NCDs control is primary prevention, with a universal NCDs prevention programme for all adults aged 40-74 years [12]. Japanese on low income had better access to the universal health care system in Japan compared to their Chinese counterparts in China. The social health insurance system in China did not prioritise outpatient costs, which would have been the most needed service for NCD patients [12]. It is important for governments to have adequate budget for prevention and promotion activities via effective channels. 
Data for the state of Sabah might not give a representative idea on the health status of a rural coastal community such as Semporna. Semporna's most dominant ethnic group is the Bajau, which constitutes $57 \%$ of the population in that district [13]. They mostly speak the Sabah Malay creole and Bajau. The Bajaus consist of individuals who hold Malaysian citizenship and those who do not. The former are also known as the Bajau Tempa$\tan$ ('emplaced Bajau') and the latter are known as the Bajau Laut. The two groups are also labelled within Sabah as simply the 'Bajau'. The Malaysian census reported that Semporna had a population of 133,164 comprising of Malaysian citizens and non-citizens [13]. Individuals who hold Malaysian citizenship have often oriented themselves to terrestrial livelihoods whilst maintaining some orientation to the marine based livelihoods, for example seaweed cultivation and fishing [14]. These groups are also more sedenterised than the Bajau Lauts who continue to ply the seas in their houseboats.

Many parts of Sabah, East Malaysia are considered rural and low income in terms of development. Populations here face significant health and nutritional challenges often observed in low-income situations. Rural health is often approached as challenges and strategies within the context of inaccessible interior regions [15] and less often within the context of coastal regions far from urban areas. However, Sabah being about half the size of Peninsular Malaysia, has challenges in health access for populations in interior regions as well as its vast coastal regions and inhabited islands. Verbal communication among health professionals indicated that non-communicable diseases in coastal regions in Sabah are largely undiagnosed, but there is no published evidence. We sought to fill this gap by conducting a cross-sectional study in Semporna, Sabah. Semporna is on the southeast of Sabah, facing the Sulawesi Sea. A similar gap in absence of NCD prevalence data for the island and coastal areas in China also presented challenges in confirming the authenticity of their published statistics [16]. Elucidation of NCD prevalence and observation of socio-economic situations in diagnosed and undiagnosed individuals will support more effective public health strategies.

\section{Methods}

\section{Study design and sampling}

This cross-sectional study was carried out in seven coastal villages on the Semporna mainland. All heads of coastal villages on the Semporna mainland that were deemed safe to visit by a local informant were visited and briefed about the study. Many areas were not accessible during the field work period because of recent armed incursions by foreigners and the resultant military operations by the Malaysian Armed Forces [17]. The local social dynamics were such that potential researchers and respondents should obtain the approval of village heads before commencement of studies. The village heads who agreed to participate provided information about number of households in their village. Based on the information gathered, invitation fliers were distributed by hand to each household $(n=355)$. The villages that agreed to participate were Kabogan Laut, Salimbangun, Pekalangan, Pokas, Tampi-Tampi Timbayan, Sum Sum and Selinggit. The inclusion criteria were that potential respondents aged $\geq 19$ years were able to communicate in Malay or Sabah Malay creole, without mental illness and physical disability, were not pregnant or lactating.

Sample size was calculated as $\mathrm{n}=\mathrm{Z}^{2} \mathrm{P}(1-\mathrm{P}) / \mathrm{d}^{2}$, where $\mathrm{p}=0.291$ based on the prevalence of hypertension of $29.1 \%$ for adults aged $\geq 18$ years in Sabah [7]. Published national data only showed prevalence by states in the federation of Malaysia. Discussions with the district nutritionist indicated that hypertension and diabetes were prevalent among adults in Semporna. As the prevalence for diabetes in Sabah was 9.0\% [7], the sample size was calculated using the prevalence of hypertension to generate a larger sample size. At $95 \%$ level of confidence and $5 \%$ precision, therefore $\mathrm{n}=1.96^{2}$ X $0.291(1-0.291) / 0.05^{2}$, a sample size of 317 adults were calculated. Stratified random sampling method was employed to recruit the respondents. There were an estimate of 1420 adults aged $\geq 19$ years in the seven villages. The population was stratified according to age group: adults aged $19-59$ years and elderly aged $\geq 60$ years to ensure we had respondents from the older adults. Respondents were recruited randomly from each stratum. Fliers were distributed throughout daylight hours everyday until all houses in all participating villages were visited. When nobody was at home, the household was visited again so that fliers could be handed in person and study information could be provided face to face and invitation to participate could be conveyed. Randomness was achieved as every household had equal chances of being visited at any daylight hour, and any potential respondent could be home at that the time of the visit. A maximum of one adult and one elderly person from each household within the inclusion criteria could freely participate as respondents. A total of 330 individuals (284 (86.1\%) individuals aged $19-59$ years; 46 (13.9\%) individuals aged $\geq 60$ years) completed the study procedures. Ethics approval was obtained from the Medical Research Ethics Committee, Faculty of Medicine and Health Sciences, Universiti Malaysia Sabah. The approval code is JKEtika 3/14(3). Preliminary groundwork to seek permissions at the study location was conducted from December 2014 to January 2015. All respondents were interviewed and biological samples were collected from February to May 2015.

\section{Study procedures}

Written informed consent was obtained from each respondent before they began their participation. Socio-demography 
and medical history data were obtained using intervieweradministered questionnaires. One researcher interviewed all respondents in their respective households. The sociodemographic data recorded were gender, age, ethnic group, religious affiliation, educational level, marital status, occupation, household income, household size and cigarette/tobacco smoking status. Medical history data were obtained using an adapted questionnaire [7]. Respondents were asked regarding family history and whether they had attended a health check in the past 12 months or diagnosed with hypertension, hypercholesterolemia and/or diabetes mellitus. Respondents were then given weekend appointments from 8 to $11 \mathrm{a} . \mathrm{m}$. at the village hall for anthropometric and blood pressure measurements and biological sampling. Body mass index (BMI), body fat, waist circumference, blood pressure, and fasting venous blood sample were obtained during this appointment. Venous blood samples were collected by a qualified health professional to determine fasting blood glucose, HDL-cholesterol, LDL-cholesterol, total cholesterol and triglycerides. Respondents were reminded to fast overnight for at least $8 \mathrm{~h}$ prior to blood sample collection. Plain water consumption was not restricted throughout that period. Respondents were asked to confirm their fasting status before a blood sample was taken. If they had not fasted or were feeling unwell, they were given another appointment for the following weekend. All blood samples were analysed in the accredited BP Diagnostic Centre, Kota Kinabalu, Sabah, Malaysia using ARCHITECT c800 Clinical Chemistry Analyser. All respondents were informed in writing of their anthropometric, blood pressure and blood sampling results. When diagnosed as hypertensive, hypercholesterolemic and/or diabetic, they were informed to seek a physician's attention with their results.

\section{Socio-demography}

Respondents were asked to state their ethnic group and religious affiliations. Educational levels were classified into five categories as 'no formal education,' 'primary,' 'lower secondary', 'upper secondary', 'foundation, matriculation, high school certificate, diploma or equivalent', and 'undergraduate degree'. Marital status was classified into four categories as 'single,' 'married,' 'divorced or separated', and 'widow/widower'. Occupation was classified into four categories as 'not working or unemployed, 'home maker,' 'self-employed' and 'public or private employee'. Cigarette smoking status was classified into three categories as 'do not smoke, 'have smoked in the past' and 'smoking'. The former two categories were merged as 'non- or ex-smoker' in data analysis.

Household income was classified into three categories as 'hardcore poor, with a household income of $\leq \mathrm{RM} 760$ / month, 'poor, with a household income of RM761 $1,180 /$ month' and 'above rural Poverty Line Income'. The hardcore poor cut-off of $\leq \mathrm{RM} 760 /$ month and Poverty Line Income of RM1,180/month for households in rural Sabah were obtained from the Economic Planning Unit, a Malaysian government agency, and based on monitoring data from January to December 2014 [18]. The Poverty Line Income (PLI) was calculated based on the minimum requirements for basic food and non-food items of every individual in a household. The basic food items were based on the Recommended Nutrient Intake and physical activity level. The non-food items were based on clothing, shoes, accommodation, fuel, utilities, basic household furniture and appliances, transportation and communication as identified by the Household Expenditure Surveys. Hardcore poverty was defined as income that is less than the cost of the basic food items [18].

\section{Anthropometric measurements}

The anthropometric measurements were conducted based on standard procedures. Height was measured to the nearest $0.1 \mathrm{~cm}$ using SECA Portable Stadiometer 213. Weight was measured to the nearest $0.1 \mathrm{~kg}$ and body fat was given as percentage of body fat using OMRON Karada Scan Body Composition Monitor HBF-375. Respondents were measured in light clothing without shoes. BMI was calculated as $\mathrm{kg} / \mathrm{m}^{2}$, and the WHO (2004) cut-offs were used: underweight $\left(<18.5 \mathrm{~kg} / \mathrm{m}^{2}\right)$, normal (18.5-22.9), overweight/pre-obese (23.0-27.4), obese I (27.5-34.9), obese II (35.0-39.9) and obese III ( $\geq 40.0)$ [19].

Percent body fat cut-offs used were: 'low body fat' [(2039 years: $<13 \%$ for men and $<25 \%$ for women), $(40-59$ years: $<13 \%$ for men and $<25 \%$ for women) and (60-79 years: $<14 \%$ for men and $<25 \%$ for women)], 'normal body fat' [(20-39 years: $13-22 \%$ for men and $25-34 \%$ for women), ( $40-59$ years: $13-23 \%$ for men and $25-34 \%$ for women) and (60-79 years: $14-23 \%$ for men and $25-35 \%$ for women)], 'moderate body fat' [(20-39 years: $23-27 \%$ for men and $35-39 \%$ for women), ( $40-59$ years: $24-28 \%$ for men and $35-40 \%$ for women) and (60-79 years: 24 $28 \%$ for men and $36-40 \%$ for women)] and 'high body fat [(20-39 years: $\geq 28 \%$ for men and $\geq 40 \%$ for women), ( 40 59 years: $\geq 29 \%$ for men and $\geq 41 \%$ for women) and (6079 years: $\geq 29 \%$ for men and $\geq 41 \%$ for women)] [20].

Waist circumference was measured to the nearest 0.1 $\mathrm{cm}$ using SECA Measuring Tape 201 to determine abdominal obesity. The cut-offs were: 'normal waist circumference' ( $<90 \mathrm{~cm}$ for men and $<80 \mathrm{~cm}$ for women) and 'positive abdominal obesity' ( $\geq 90 \mathrm{~cm}$ for men and $\geq$ $80 \mathrm{~cm}$ for women) [21].

\section{Blood pressure measurements}

Blood pressure was measured using OMRON Automatic Blood Pressure Monitor SEM-1. Respondents were measured in a rested and seated condition at their village hall. At least two measurements were performed at five minutes apart on respondents' right arm rested on a table at heart level. If the two systolic and diastolic 
readings did not differ by more than $5 \mathrm{mmHg}$, the average of these values was used as the blood pressure value for that individual. If the readings from the initial two measurements differed more than $5 \mathrm{mmHg}$, subsequent measurements were taken 5-10 min later until two values within the acceptable difference were obtained. The Malaysian Ministry of Health's Clinical Practice Guidelines for Hypertension cut-offs for blood pressure were used: 'optimal' $(<120 \mathrm{mmHg}$ for systolic and $<80$ $\mathrm{mmHg}$ for diastolic), 'normal' (<130 mmHg for systolic and $<85 \mathrm{mmHg}$ for diastolic), 'high normal' (130-139 $\mathrm{mmHg}$ for systolic and/or $85-89 \mathrm{mmHg}$ for diastolic), 'hypertension I' (140-159 mmHg for systolic and/or 90$99 \mathrm{mmHg}$ for diastolic), 'hypertension II' (160-179 $\mathrm{mmHg}$ for systolic and/or 100-109 $\mathrm{mmHg}$ for diastolic) and 'hypertension III' ( $\geq 180 \mathrm{mmHg}$ for systolic and/or $\geq$ $110 \mathrm{mmHg}$ for diastolic) [22].

\section{Blood glucose and lipids cut-offs}

The Malaysian Ministry of Health's Clinical Practice Guidelines on type 2 diabetes mellitus cut-offs for fasting blood glucose were used: 'normal blood glucose' (< $7.0 \mathrm{mmol} / \mathrm{L}$ ) and 'positive diabetes mellitus' ( $\geq 7.0)$ [23]. The blood lipids cut-offs from the National Cholesterol Education Programme were used. Total cholesterol cut-offs were: 'normal' (<5.2 mmol/L), 'borderline high' (5.2-6.1) and 'high' ( $\geq 6.2)$. Triglyceride cut-offs were: 'normal' $<1.7 \mathrm{mmol} / \mathrm{L}$, 'borderline high' $(1.7-2.2 \mathrm{mmol} /$ L), 'high' $(2.3-5.6 \mathrm{mmol} / \mathrm{L})$ and 'very high' $(\geq 5.7 \mathrm{mmol} /$ L). LDL cholesterol cut-offs were: 'normal' $(<2.6 \mathrm{mmol} /$ L), 'above normal' (2.6-3.3 mmol/L), 'borderline high' (3.4-4.1 mmol/L), 'high' (4.2-4.8 $\mathrm{mmol} / \mathrm{L})$ and 'very high' $(\geq 4.9 \mathrm{mmol} / \mathrm{L})$. HDL cholesterol cut-offs were: 'low' (< $1.0 \mathrm{mmol} / \mathrm{L})$, 'normal' (1.0-1.5 mmol/L) and 'high' ( $\geq 1.6$ $\mathrm{mmol} / \mathrm{L})[24]$.

\section{Statistical analyses}

All data were analysed using IBM SPSS Statistics 24. Kolmogorov-Smirnov test was used to assess for the Normal distribution; $\mathrm{P}>0.05$ was considered to be Normally distributed. The results were presented as frequencies (N) and percentages (\%) for categorical variables and as means and standard deviations (S.D.) for continuous variables. Chi-square test was used to determine associations between categorical variables. Binary logistic regression was attempted with each disease as the dependent variable; and gender, age group, education level, household income level, occupation categories, waist circumference and BMI as independent variables in the full model. Unpaired t-test and Mann-Whitney test were used to determine differences between two groups for continuous variable. One-way ANOVA with Tukey's b post hoc test and Kruskal-Wallis test were used to determine differences between three or more groups for continuous variables. $\mathrm{P}<0.05$ was considered to be statistically significant.

\section{Results \\ Socio-demography}

A total of 330 adults (133 males, 197 females) participated in this study out of 355 individuals who were approached during the door-to-door recruitment. There were mostly one respondent from each household. The response rate was about $93 \%$. Mean age was $43.7 \pm 15.8$ years. Most of the respondents were individuals aged 30-59 years (64.8\%) and described themselves as belonging to the Bajau ethnic group (98.2\%). All respondents described themselves as Muslims. Most respondents were educated to secondary school level (47.9\%). The men were mainly self-employed ( $\mathrm{n}=83,62.4 \%)$. Most self-employed men were fishermen $(n=32,38.6 \%$ of those self-employed), private bus drivers $(\mathrm{n}=15,18.15 \%)$ and farmers $(\mathrm{n}=11$, $13.3 \%)$. The women were mainly housewives $(n=144$, 73.1\%). Household income were mostly below Poverty Line Income for households in rural Sabah of RM1, 180/ month [18]; 14.2\% were poor (household income RM761$1180 /$ month) and $72.4 \%$ were hardcore poor (household income $\leq \mathrm{RM} 760 /$ month). Most households in Semporna had more than 6 individuals per household (60.9\%). Median per capita household income was RM83.33/month. Only $11.5 \%$ of respondents smoked cigarettes. More details are reported in Table 1.

\section{Non-communicable diseases}

A total of 108 (32.7\%) respondents were identified as hypertensive; 81 respondents $(24.5 \%)$ had never been diagnosed by a health professional. Of those who had been previously diagnosed $(n=27), 11(40.7 \%)$ had well controlled blood pressure, and 16 (59.3\%) had uncontrolled blood pressure readings. There were 225 individuals (68.2\%) who had not had their blood pressure checked in the preceding 12 months. Of these 225 individuals, 64 (28.4\%) were found to have undiagnosed elevated blood pressure. Of those with undiagnosed elevated blood pressure, $79.0 \%$ were those who did not have a blood pressure check $(p<0.001)$.

The number of hypercholesterolemic respondents was 140 (42.4\%); 134 respondents (40.6\%) had never been diagnosed by a health professional. Of those who had been previously diagnosed $(n=6)$, only $1(16.7 \%)$ respondent had well controlled total cholesterol levels, and 5 (83.3\%) had poorly controlled total cholesterol levels. There were 303 individuals (91.8\%) who had not had their blood lipids checked in the preceding 12 months. Of these 303 individuals, 129 (42.6\%) were found to have undiagnosed elevated total cholesterol. Among those who were undiagnosed, $96.3 \%$ were those who did not have a blood lipids check $(p<0.001)$. 
Table 1 Socio-demographic characteristics of respondents

\begin{tabular}{|c|c|c|c|c|c|c|}
\hline \multirow[t]{3}{*}{ Characteristics } & \multicolumn{4}{|c|}{ Sex, N (column \%) } & \multirow{2}{*}{\multicolumn{2}{|c|}{ All $(n=330)$}} \\
\hline & \multicolumn{2}{|c|}{ Men $(n=133)$} & \multicolumn{2}{|c|}{ Women $(n=197)$} & & \\
\hline & $\bar{N}$ & $(\%)$ & $\mathrm{N}$ & (\%) & $\bar{N}$ & $(\%)$ \\
\hline Age group (years) & \multicolumn{2}{|c|}{$43.0 \pm 16.4^{\mathrm{a}}$} & \multicolumn{2}{|c|}{$44.1 \pm 15.4^{a}$} & \multicolumn{2}{|c|}{$43.7 \pm 15.8^{\mathrm{a}}$} \\
\hline $19-29$ & 32 & $(24.1)$ & 38 & $(19.3)$ & 70 & $(21.3)$ \\
\hline $30-59$ & 80 & $(60.2)$ & 134 & $(68.0)$ & 214 & $(64.8)$ \\
\hline$\geq 60$ & 21 & $(15.8)$ & 25 & $(12.7)$ & 46 & $(13.9)$ \\
\hline \multicolumn{7}{|l|}{ Ethnic group } \\
\hline Bajau & 131 & $(98.5)$ & 193 & $(98.0)$ & 324 & $(98.2)$ \\
\hline Bugis & 0 & $(0.0)$ & 2 & (1.0) & 2 & $(0.6)$ \\
\hline Jawa & 1 & $(0.8)$ & 0 & $(0.0)$ & 1 & $(0.3)$ \\
\hline Suluk & 1 & $(0.8)$ & 1 & $(0.5)$ & 2 & $(0.6)$ \\
\hline Sungai & 0 & $(0.0)$ & 1 & $(0.5)$ & 1 & $(0.3)$ \\
\hline \multicolumn{7}{|l|}{ Religion } \\
\hline Islam & 133 & $(100.0)$ & 197 & $(100.0)$ & 330 & $(100.0)$ \\
\hline \multicolumn{7}{|l|}{ Educational level } \\
\hline No formal education & 20 & $(15.0)$ & 63 & $(32.0)$ & 83 & $(25.2)$ \\
\hline Primary school & 26 & $(19.5)$ & 39 & (19.8) & 65 & $(19.7)$ \\
\hline Secondary school & 75 & $(56.4)$ & 83 & $(42.1)$ & 158 & $(47.9)$ \\
\hline High school certificate / Diploma & 7 & $(5.3)$ & 9 & $(4.6)$ & 16 & $(4.8)$ \\
\hline Bachelor's degree & 5 & $(3.8)$ & 3 & $(1.5)$ & 8 & $(2.4)$ \\
\hline \multicolumn{7}{|l|}{ Marital status } \\
\hline Single & 39 & $(29.3)$ & 38 & $(19.3)$ & 77 & $(23.3)$ \\
\hline Married & 88 & $(66.2)$ & 128 & $(65.0)$ & 216 & $(65.5)$ \\
\hline Divorced/Separated & 0 & $(0.0)$ & 2 & $(1.0)$ & 2 & $(0.6)$ \\
\hline Widow/Widower & 6 & $(4.5)$ & 29 & $(14.7)$ & 35 & $(10.6)$ \\
\hline \multicolumn{7}{|l|}{ Occupation } \\
\hline Unemployed & 32 & $(24.1)$ & 31 & $(15.7)$ & 63 & $(19.1)$ \\
\hline Housewife & 0 & $(0.0)$ & 144 & $(73.1)$ & 144 & $(43.6)$ \\
\hline Self-employed & 83 & $(62.4)$ & 19 & (9.6) & 102 & $(30.9)$ \\
\hline Employed & 18 & $(13.5)$ & 3 & $(1.5)$ & 21 & $(6.4)$ \\
\hline Household income (RM/month) & \multicolumn{2}{|c|}{$750.0 \pm 713.0^{a}$} & \multicolumn{2}{|c|}{$618.8 \pm 443.6^{a}$} & \multicolumn{2}{|c|}{$671.7 \pm 569.9^{a}$} \\
\hline Hardcore poor & 97 & $(72.9)$ & 142 & $(72.1)$ & 239 & $(72.4)$ \\
\hline Poor & 15 & $(11.3)$ & 32 & $(16.2)$ & 47 & $(14.2)$ \\
\hline Above PLI & 21 & $(15.8)$ & 23 & $(11.7)$ & 44 & $(13.3)$ \\
\hline Household size (Number of individuals) & \multicolumn{2}{|c|}{$6.4 \pm 3.1^{a}$} & \multicolumn{2}{|c|}{$6.8 \pm 3.2^{\mathrm{a}}$} & \multicolumn{2}{|c|}{$6.7 \pm 3.2^{\mathrm{a}}$} \\
\hline $1-5$ & 59 & $(44.4)$ & 70 & $(35.5)$ & 129 & $(39.1)$ \\
\hline$\geq 6$ & 74 & $(55.6)$ & 127 & $(64.5)$ & 201 & $(60.9)$ \\
\hline \multicolumn{7}{|l|}{ Smoking status } \\
\hline Smoker & 31 & $(23.3)$ & 7 & (3.6) & 38 & $(11.5)$ \\
\hline Non/Ex-smoker & 102 & $(76.7)$ & 190 & $(96.4)$ & 292 & $(88.5)$ \\
\hline
\end{tabular}

a Values are in mean \pm S.D.

A total of 24 respondents $(7.3 \%)$ were identified as diabetic; 19 respondents $(5.8 \%)$ had never been diagnosed by a health professional. Of those who had been previously diagnosed $(n=5), 3(60 \%)$ respondents had well controlled fasting blood glucose and 2 had poorly controlled levels (40\%). There were 287 individuals $(87.0 \%)$ who had not 
had their blood glucose checked in the preceding 12 months. Of these 287 individuals, 17 (5.9\%) were found to have undiagnosed elevated fasting blood glucose. Among those who were undiagnosed, $89.5 \%$ were those who did not have a blood glucose check ( $<<0.001)$.

As expected, older individuals were more represented among those with hypertension, hypercholesterolemia and diabetes mellitus $(\mathrm{p}=0.001)$. For hypertension, the OR for respondents aged $30-59 y$ was 0.34 (95\% CI: 0.14-0.79, $\mathrm{p}=0.012$ ) compared to respondents aged $\geq 60 \mathrm{y}$. The $\geq 60 \mathrm{y}$ age group had the highest number of individuals with hypertension. For diabetes mellitus, the OR for respondents aged $30-59 y$ was 0.21 (95\% CI: 0.06-0.75, $\mathrm{p}=0.016$ ) compared to respondents aged $\geq 60 y$. The $30-59 y$ age group had the highest number of individuals with diabetes mellitus and hypercholesterolemia. More details are shown in Tables 2 and 3.

Adults with lower educational levels were more represented among those with hypertension and hypercholesterolemia $(p<0.001)$ (Table 2$)$. For hypertension, the OR for respondents with no formal education was 40.1 (95\% CI: 2.77-581.52, $\mathrm{p}=0.007$ ) compared to respondents with an undergraduate degree level of education. The OR for hypertension decreased as education level increased (Table 3).

Adults form hardcore poor households were the most represented in those who did not have a blood pressure, blood sugar and blood lipids check in the 12 months preceding this present study $(p<0.01)$. More details are reported in Table 4. Individuals living in hardcore poor households who had not been previously diagnosed with NCDs also had significantly higher systolic blood pressure, total cholesterol, LDL-cholesterol and fasting blood glucose compared to individuals in similar economic situation who were without the NCD or had been diagnosed with it $(p<0.001)$. Fasting blood glucose was significantly higher in non-diabetic individuals living in hardcore poor households compared to non-diabetic individuals in poor and above PLI households $(p=0.006)$. More details are reported in Table 5. Respondents who were obese, had very high body fat percentage and positive abdominal obesity were significantly represented among those who had hypertension, hypercholesterolemia and diabetes mellitus $(p<0.001)$. More details are reported in Table 6.

\section{Discussion}

Hypercholesterolemia (42.4\%) was the most prevalent NCD, followed by hypertension (32.7\%) and diabetes mellitus (7.3\%) in Semporna, Sabah. These are comparable to the national prevalence in rural areas of $47.7 \%$ for hypercholesterolemia and $33.5 \%$ for hypertension [4]. The prevalence for diabetes mellitus in Semporna was half of the national prevalence in rural areas of $16.7 \%$ for diabetes [4]. The Sabah state's prevalence for hypercholesterolemia was $40.9 \%$, hypertension was $26.8 \%$ and diabetes mellitus was $14.2 \%$ [4]. The prevalence for diabetes was lower in Semporna despite $202(61.2 \%)$ of respondents were found to have abdominal obesity. In comparison, the prevalence of abdominal obesity was $46.4 \%$ for the state of Sabah, $48.6 \%$ for the country, and $46.2 \%$ for rural areas throughout the country [4]. These differences could be attributable to differences in genetics and food intake. It has been demonstrated that indigenous Sarawakians in the northwestern part of Borneo island, had higher adjusted prevalence ratios for metabolic syndrome compared to ethnic Malays and Chinese in Malaysia [25]. The staple food of the Bajau Lauts, a marine nomadic group, was tapioca, rice and fish [26]. The settled Bajau shared similar food culture with the Bajau Lauts. The Bajau Lauts had recently been shown to have genetic variants in the PDE10A gene which resulted in increased spleen sizes [27]. The spleen might have a physiological role in diabetes mellitus as demonstrated by splenectomised patients who had significantly higher mean glucose level $(114 \mathrm{mg} / \mathrm{dL})$ than in the control group (90 $\mathrm{mg} / \mathrm{dL}) \quad(\mathrm{p}=0.04)$ [28]. These findings showed that the coastal communities in Sabah were not similar to Malaysians from other regions and of other ethnic groups in terms of risk factors of NCDs.

It is important to note that the prevalence of hypertension in this rural coastal community was higher than the Sabah state wide prevalence. A similar trend in prevalence of hypertension was noted among adults from coastal areas and islands in China in the 2000s. The estimated prevalence in Chinese coastal areas was $29.1 \%$ (95\%CI:24.8-33.9) and in island regions was $33.9 \%$ (955\%CI: 29.4-38.8) compared to China's pooled, adjusted national prevalence of 20.3\% (95\%CI:14.1-28.4) [16]. Several studies on hypertension among rural adults in Peninsular Malaysia (also known as West Malaysia) reported comparable prevalence of $26.8-33.6 \%$ [2, 3, 29]. The only reported study conducted in three islands within marine park areas in Peninsular Malaysia reported very much lower rates of hypertension (10.7\%) and diabetes (0.7\%) [30]. In 1985, prevalence of hypertension in rural areas of developing island nations like Vanuatu was lower than that of urban areas. It was $1.1 \%$ for rural men and $2.6 \%$ for rural women compared to $6.0 \%$ for urban men and $4.2 \%$ in urban women in Vanuatu [31]. By 2007, 19.7\% of households on a rural island in Vanuatu were reporting that they had family members with hypertension or cardiovascular diseases compared to $45.1 \%$ in an urban area [32]. Increasing sedentary activities and changes in economic activities seemed to increase prevalence levels in rural islands and rural coastal areas to urban prevalence levels in 
Table 2 Prevalence of hypertension (HPN), hypercholesterolemia (HPC) and diabetes mellitus (DM) by socio-demography of respondents

\begin{tabular}{|c|c|c|c|c|c|c|c|c|c|c|c|c|c|c|c|}
\hline \multirow[t]{3}{*}{ Risk factors } & \multicolumn{4}{|c|}{$\begin{array}{l}\text { Hypertension, } \\
\text { N (row \%) }\end{array}$} & \multirow[t]{3}{*}{$\begin{array}{l}\text { Chi-square/ } \\
p \text {-value }\end{array}$} & \multicolumn{4}{|c|}{$\begin{array}{l}\text { Hypercholesterolemia, } \\
\text { N (row \%) }\end{array}$} & \multirow[t]{3}{*}{$\begin{array}{l}\text { Chi-square/ } \\
p \text {-value }\end{array}$} & \multicolumn{4}{|c|}{$\begin{array}{l}\text { Diabetes Mellitus, } \\
\text { N (row \%) }\end{array}$} & \multirow[t]{3}{*}{$\begin{array}{l}\text { Chi-square, } \\
p \text {-value }\end{array}$} \\
\hline & \multicolumn{2}{|c|}{$\begin{array}{l}\text { HPN } \\
(n=108) \\
\end{array}$} & \multicolumn{2}{|c|}{$\begin{array}{l}\text { Non-HPN } \\
(n=222)\end{array}$} & & \multicolumn{2}{|c|}{$\begin{array}{l}\mathrm{HPC} \\
(n=140)\end{array}$} & \multicolumn{2}{|c|}{$\begin{array}{l}\text { Non-HPC } \\
(n=190)\end{array}$} & & \multicolumn{2}{|c|}{$\begin{array}{l}\mathrm{DM} \\
(n=24)\end{array}$} & \multicolumn{2}{|c|}{$\begin{array}{l}\text { Non-DM } \\
(n=306) \\
\end{array}$} & \\
\hline & $\mathrm{N}$ & (\%) & $\mathrm{N}$ & $(\%)$ & & $\mathrm{N}$ & (\%) & $\mathrm{N}$ & $(\%)$ & & $\mathrm{N}$ & (\%) & $\mathrm{N}$ & (\%) & \\
\hline Sex & & & & & $0.133 /$ & & & & & $0.303 /$ & & & & & $0.523 /$ \\
\hline Men & 42 & (31.6) & 91 & $(68.4)$ & 0.715 & 54 & $(40.6)$ & 79 & $(59.4)$ & 0.582 & 8 & $(6.0)$ & 125 & $(94.0)$ & 0.524 \\
\hline Women & 66 & (33.5) & 131 & $(66.5)$ & & 86 & $(43.7)$ & 111 & $(56.3)$ & & 16 & $(8.1)$ & 181 & $(91.9)$ & \\
\hline Age group (years) & & & & & $32.226 /$ & & & & & $21.754 /$ & & & & & $13.058 /$ \\
\hline $19-29$ & 9 & $(11.2)$ & 71 & $(88.8)$ & $<0.001$ & 16 & $(20.0)$ & 64 & $(80.0)$ & $<0.001$ & 0 & $(0.0)$ & 80 & $(100.0)$ & 0.001 \\
\hline $30-59$ & 75 & $(35.5)$ & 136 & $(64.5)$ & & 105 & $(49.8)$ & 106 & $(50.2)$ & & 17 & $(8.1)$ & 194 & $(91.9)$ & \\
\hline$\geq 60$ & 24 & (61.5) & 15 & (38.5) & & 19 & $(48.7)$ & 20 & $(51.3)$ & & 7 & $(17.9)$ & 32 & $(82.1)$ & \\
\hline Educational level & & & & & $32.218 /$ & & & & & $34.319 /$ & & & & & $5.237 /$ \\
\hline No formal education & 47 & (56.6) & 36 & (43.4) & $<0.001$ & 56 & $(67.5)$ & 27 & $(32.5)$ & $<0.001$ & 9 & $(10.8)$ & 74 & $(89.2)$ & 0.264 \\
\hline Primary school & 21 & (32.3) & 44 & $(67.7)$ & & 26 & $(40.0)$ & 39 & $(60.0)$ & & 5 & $(7.7)$ & 60 & $(92.3)$ & \\
\hline Secondary school & 37 & (23.4) & 121 & (76.6) & & 52 & $(32.9)$ & 106 & $(67.1)$ & & 10 & $(6.3)$ & 148 & $(93.7)$ & \\
\hline $\begin{array}{l}\text { High School Certificate/ } \\
\text { Diploma }\end{array}$ & 2 & $(12.5)$ & 14 & (87.5) & & 2 & $(12.5)$ & 14 & $(87.5)$ & & 0 & $(0.0)$ & 16 & (100.0) & \\
\hline Bachelor's degree & 1 & $(12.5)$ & 7 & $(87.5)$ & & 4 & $(50.0)$ & 4 & $(50.0)$ & & 0 & $(0.0)$ & 8 & $(100.0)$ & \\
\hline Marital status & & & & & 19.410/ & & & & & $21.696 /$ & & & & & $8.725 /$ \\
\hline Single & 12 & (15.6) & 65 & (84.4) & $<0.001$ & 18 & $(23.4)$ & 59 & (76.6) & $<0.001$ & 1 & (1.3) & 76 & $(98.7)$ & 0.033 \\
\hline Married & 76 & $(35.2)$ & 140 & $(64.8)$ & & 100 & $(46.3)$ & 116 & $(53.7)$ & & 18 & $(8.3)$ & 198 & $(91.7)$ & \\
\hline Divorced/Separated & 1 & $(50.0)$ & 1 & $(50.0)$ & & 0 & $(0.0)$ & 2 & $(100.0)$ & & 0 & $(0.0)$ & 2 & $(100.0)$ & \\
\hline Widow/Widower & 19 & $(54.3)$ & 16 & $(45.7)$ & & 22 & $(62.9)$ & 13 & $(37.1)$ & & 5 & $(14.3)$ & 30 & $(85.7)$ & \\
\hline Occupation & & & & & $11.521 /$ & & & & & $11.494 /$ & & & & & $3.375 /$ \\
\hline Unemployed & 11 & $(17.5)$ & 52 & (82.5) & 0.009 & 15 & $(23.8)$ & 48 & $(76.2)$ & 0.009 & 2 & $(3.2)$ & 61 & $(96.8)$ & 0.337 \\
\hline Housewife & 56 & (38.9) & 88 & $(61.1)$ & & 70 & $(48.6)$ & 74 & $(51.4)$ & & 12 & $(8.3)$ & 132 & $(91.7)$ & \\
\hline Self-employed & 31 & $(30.4)$ & 71 & (69.6) & & 46 & $(45.1)$ & 56 & $(54.9)$ & & 6 & $(5.9)$ & 96 & $(94.1)$ & \\
\hline Employed & 10 & $(47.6)$ & 11 & $(52.4)$ & & 9 & $(42.9)$ & 12 & $(57.1)$ & & 1 & $(4.8)$ & 20 & $(95.2)$ & \\
\hline Household income (RM/month) & & & & & $0.450 /$ & & & & & $0.837 /$ & & & & & $0.095 /$ \\
\hline Hardcore poor & 78 & (32.6) & 161 & $(67.4)$ & 0.799 & 101 & $(42.3)$ & 138 & $(57.7)$ & 0.658 & 18 & $(7.5)$ & 221 & $(92.5)$ & 0.954 \\
\hline Poor & 14 & $(29.8)$ & 33 & $(70.2)$ & & 18 & $(38.3)$ & 29 & $(61.7)$ & & 3 & $(6.4)$ & 44 & $(93.6)$ & \\
\hline Above PLI & 16 & $(36.4)$ & 28 & (63.6) & & 21 & $(47.7)$ & 23 & $(52.3)$ & & 3 & $(12.5)$ & 41 & $(93.2)$ & \\
\hline Household size (People) & & & & & $0.035 /$ & & & & & $0.724 /$ & & & & & $0.360 /$ \\
\hline $1-5$ & 43 & (33.3) & 86 & $(66.7)$ & 0.851 & 51 & $(39.5)$ & 78 & $(60.5)$ & 0.395 & 8 & $(6.2)$ & 121 & (93.8) & 0.666 \\
\hline$\geq 6$ & 65 & $(32.3)$ & 136 & $(67.7)$ & & 89 & $(44.3)$ & 112 & $(55.7)$ & & 16 & $(8.0)$ & 185 & $(92.0)$ & \\
\hline Smoking status & & & & & $0.043 /$ & & & & & $1.832 /$ & & & & & $1.372 /$ \\
\hline Smoker & 13 & $(34.2)$ & 25 & $(65.8)$ & & 20 & $(52.9)$ & 18 & $(47.4)$ & & 1 & $(2.6)$ & 37 & $(97.4)$ & \\
\hline Non/Ex-smoker & 95 & $(32.5)$ & 197 & $(67.5)$ & & 120 & $(41.1)$ & 172 & $(58.9)$ & & 23 & (7.9) & 269 & $(92.1)$ & \\
\hline
\end{tabular}

developing countries such as the South Pacific island countries [32] and China [33].

The occurrence of these three NCDs increased significantly with increasing age, BMI, percent body fat and waist circumference $(\mathrm{p}<0.05)$. Other studies in Malaysia also reported similar observations [2, 3, 29, 34]. As waist circumference increased, the $\mathrm{OR}$ for hypertension $(\mathrm{OR}=$
1.09, 95\%CI: $1.04-1.14, \mathrm{p}<0.001)$ and for diabetes $(\mathrm{OR}=$ 1.07, 95\%CI: 1.00-1.15, $\mathrm{p}=0.044$ ) increased (Table 3). In Asian populations, waist circumference might be a more appropriate indicator of obesity and insulin resistance [35]. Obesity had increased in Asian populations with the gap between rural and urban communities narrowing. In a longitudinal study on Filipino women, 
Table 3 Odd ratios for hypertension, hypercholesterolemia and diabetes mellitus

\begin{tabular}{|c|c|c|c|c|c|c|c|c|c|}
\hline & \multicolumn{3}{|c|}{$\begin{array}{l}\text { Hypertension (yes vs. no), } \\
\left.\text { Nagelkerke } R^{2}=0.351\right), \\
\text { overall predictive } \\
\text { accuracy }=75.5 \%\end{array}$} & \multicolumn{3}{|c|}{$\begin{array}{l}\text { Hypercholesterolemia (yes vs. no), } \\
\text { Nagelkerke } R^{2}=0.253 \text { ), overall } \\
\text { predictive accuracy }=68.2 \%\end{array}$} & \multicolumn{3}{|c|}{$\begin{array}{l}\text { Diabetes mellitus }{ }^{\mathrm{a}} \text { (yes vs. no), } \\
\text { Nagelkerke } \mathrm{R}^{2}=0.270 \text {, overall } \\
\text { predictive accuracy }=93.0 \%\end{array}$} \\
\hline & $\overline{\mathrm{OR}}$ & $(95 \% \mathrm{Cl})$ & $\overline{P \text { value }}$ & $\overline{\mathrm{OR}}$ & $(95 \% \mathrm{Cl})$ & $P$ value & $\overline{\mathrm{OR}}$ & $(95 \% \mathrm{Cl})$ & $P$ value \\
\hline \multicolumn{10}{|l|}{$\begin{array}{l}\text { Education level with undergraduate } \\
\text { degree as the reference }\end{array}$} \\
\hline No formal education & 40.1 & $(2.77-581.52)$ & 0.007 & 2.66 & $(0.33-21.62)$ & 0.361 & & & \\
\hline Primary & 15.4 & $(1.09-217.12)$ & 0.043 & 0.74 & $(0.10-5.64)$ & 0.769 & & & \\
\hline Lower secondary & 14.5 & $(1.06-197.14)$ & 0.045 & 0.74 & $(0.10-5.40)$ & 0.758 & & & \\
\hline Upper secondary & 14.1 & $(1.02-196.13)$ & 0.048 & 0.44 & $(0.06-3.30)$ & 0.427 & & & \\
\hline High school certificate /diploma & 13.7 & $(0.57-326.01)$ & 0.106 & 0.24 & $(0.02-3.00)$ & 0.262 & & & \\
\hline \multicolumn{10}{|l|}{$\begin{array}{l}\text { Household income with above PLI } \\
\text { as the reference }\end{array}$} \\
\hline Hardcore poor & 0.48 & $(0.18-1.27)$ & 0.139 & 0.34 & $(0.14-0.85)$ & 0.020 & 0.56 & $(0.09-3.36)$ & 0.525 \\
\hline Poor & 0.53 & $(0.17-1.60)$ & 0.256 & 0.48 & $(0.17-1.34)$ & 0.161 & 0.65 & $(0.08-5.20)$ & 0.688 \\
\hline \multicolumn{10}{|l|}{$\begin{array}{l}\text { Occupation with public / private } \\
\text { employee as the reference }\end{array}$} \\
\hline Unemployed & 0.27 & $(0.05-1.47)$ & 0.129 & 2.04 & $(0.42-9.79)$ & 0.375 & 3.83 & $(0.15-99.29)$ & 0.418 \\
\hline Home maker & 0.29 & $(0.05-1.79)$ & 0.182 & 2.23 & $(0.44-11.45)$ & 0.336 & 3.43 & $(0.12-101.34)$ & 0.476 \\
\hline Self employed & 0.28 & $(0.06-1.31)$ & 0.106 & 2.64 & $(0.62-11.22)$ & 0.187 & 1.98 & $(0.12-33.22)$ & 0.634 \\
\hline \multicolumn{10}{|l|}{ Age with $\geq 60 y$ as the reference } \\
\hline $19-29 y$ & 0.37 & $(0.10-1.40)$ & 0.143 & 1.70 & $(0.52-5.57)$ & 0.384 & 0 & 0 & 0.997 \\
\hline $30-59 y$ & 0.34 & $(0.14-0.79)$ & 0.012 & 1.59 & $(0.71-3.58)$ & 0.260 & 0.21 & $(0.06-0.75)$ & 0.016 \\
\hline \multicolumn{10}{|l|}{ Gender with females as the reference } \\
\hline Males & 1.96 & $(0.62-6.15)$ & 0.252 & 2.44 & $(0.92-6.48)$ & 0.074 & 2.16 & $(0.26-17.67)$ & 0.473 \\
\hline Waist circumference (cm) & 1.09 & $(1.04-1.14)$ & $<0.001$ & 1.04 & $(1.00-1.08)$ & 0.085 & 1.07 & $(1.00-1.15)$ & 0.044 \\
\hline BMI $\left(\mathrm{kg} / \mathrm{m}^{2}\right)$ & 1.20 & $(0.77-1.86)$ & 0.543 & 0.86 & $(0.58-1.29)$ & 0.472 & 1.09 & $(0.41-2.90)$ & 0.867 \\
\hline
\end{tabular}

a OR for education level for diabetes was not reported as there were no respondents who were diabetic with foundation / high school / diploma and undergraduate degree levels

diabetes was associated with higher waist circumference in relation to higher socioeconomic status and urbanisation [36]. An Indonesian cross-sectional study also showed waist circumference was associated with blood glucose levels [37]. Higher salt intake was associated with higher prevalence of hypertension in coastal rural communities in India [38, 39]. The most recent Malaysian nationally representative data (MANS 2014) on nutrient intake showed that the indigenous population in Sabah had a higher median sodium intake $(2026 \mathrm{mg})$ compared to the national median (1935 mg) [40].

The prevalence of undiagnosed hypertension (24.5\%), hypercholesterolemia (40.6\%) and diabetes mellitus (5.8\%) in this rural coastal community were comparable to the Malaysian national prevalence of undiagnosed NCDs in rural areas, which were $20.7,40.5$ and $9.5 \%$ respectively. In contrast, the Malaysian national prevalence of undiagnosed NCDs in urban areas were 16.1, 38.0 and 9.1\% respectively [4]. The REDISCOVER study on hypertension in Malaysia found that awareness, treatment and control among hypertensive respondents were significantly lower in rural communities compared to their urban counterparts [5]. Similarly, rural hypertensive adults in China were $49.4 \%$ less likely to be detected and $89.5 \%$ less likely to be medicated than their urban counterparts [41].

The over-representations of individuals from hardcore poor households in the undiagnosed NCDs $(p<0.001)$ and among those who did not have a health check in the preceding 12 months $(p<0.001)$ are a matter of public health concern. Blood pressure is the easiest to administer compared to blood lipids and blood glucose checks. Yet, only $68.2 \%$ of adults in Semporna had access to a blood pressure check in the preceding 12 months. This rate of access had not improved over the 25 years since Gan \& Chin reported an access rate of $70.4 \%$ for rural populations in Sabah [42]. At that time, the prevalence for hypertension in Kota Belud, another rural community in north-western Sabah was $20.1 \%$ [42], which was slightly lower than the prevalence of $24.5 \%$ reported for this Semporna study. The high prevalence of undiagnosed NCDs 
Table 4 Access to health checks by economic status of households

\begin{tabular}{|c|c|c|c|c|}
\hline & \multirow{2}{*}{$\begin{array}{l}\text { Economic status } \\
\text { of household }\end{array}$} & \multicolumn{2}{|c|}{ Had a health check in the preceding 12 months } & \multirow{2}{*}{$\begin{array}{l}\text { Chi square } \\
\text { test, } p \text { value }\end{array}$} \\
\hline & & No, n (row\%) & Yes, n (row \%) & \\
\hline \multirow[t]{3}{*}{ Blood pressure check } & Hardcore poor & $178(74.5)$ & $61(25.5)$ & \multirow[t]{3}{*}{$<0.001$} \\
\hline & Poor & $30(63.8)$ & $17(36.2)$ & \\
\hline & Above PLI & 17 (38.6) & $27(61.4)$ & \\
\hline \multirow[t]{3}{*}{ Blood lipids check } & Hardcore poor & $226(94.6 \%)$ & $13(5.4)$ & \multirow[t]{3}{*}{0.009} \\
\hline & Poor & $42(89.4)$ & $5(10.6)$ & \\
\hline & Above PLI & $35(79.5)$ & $9(20.5)$ & \\
\hline \multirow[t]{3}{*}{ Blood glucose check } & Hardcore poor & $220(92.1)$ & $19(7.9)$ & \multirow[t]{3}{*}{$<0.001$} \\
\hline & Poor & $36(76.6)$ & $11(23.4)$ & \\
\hline & Above PLI & $31(70.5)$ & $13(29.5)$ & \\
\hline
\end{tabular}

among respondents in the present study could be related to low health consciousness in the community. Results showed that only a small proportion of respondents had undergone health check-up for hypertension (31.8\%), hypercholesterolemia (8.2\%) and diabetes mellitus (13.0\%). NCDs could be asymptomatic which caused individuals to not seek health checks as they perceived themselves as healthy [10]. Low health consciousness in the community could be a result of approaches which were disease focused. When a continuous health programme was designed to be family focused within rural communities in Western Sabah, it was found that many families were

Table 5 Blood pressure and blood chemistry by status of diagnosis of hypertension (HPN), hypercholesterolemia (HPC) and diabetes mellitus (DM) according to household income levels

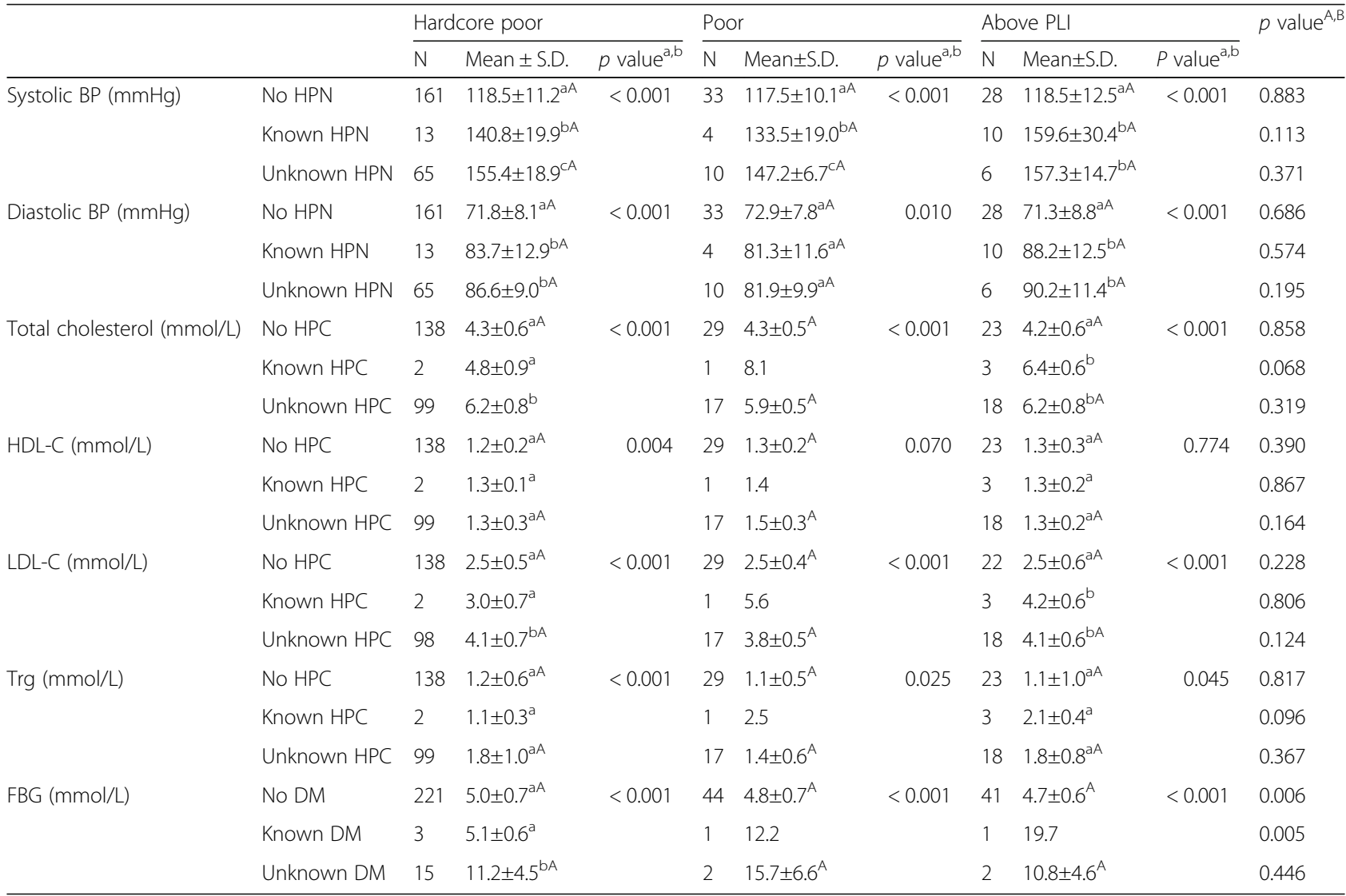

a,b Different superscripts within the same column denote significant difference between NCD status $(p<0.05)$ for each blood chemistry. The group sizes are unequal. Type I error levels might occur for the ANOVA

A, B Different superscripts within the same row denote significant difference between household income levels $(p<0.05)$ for each blood chemistry. The group sizes are unequal. Type I error levels might occur for the ANOVA 
Table 6 Prevalence of hypertension (HPN), hypercholesterolemia (HPC) and diabetes mellitus (DM) by nutritional status of respondents

\begin{tabular}{|c|c|c|c|c|c|c|c|c|c|c|c|c|c|c|c|}
\hline \multirow[t]{3}{*}{ Risk factors } & \multicolumn{4}{|c|}{$\begin{array}{l}\text { Hypertension, } \\
\text { N (row \%) }\end{array}$} & \multirow[t]{3}{*}{$\begin{array}{l}\text { Chi-square/ } \\
\text { p-value }\end{array}$} & \multicolumn{4}{|c|}{$\begin{array}{l}\text { Hypercholesterolemia, } \\
\text { N (row \%) }\end{array}$} & \multirow[t]{3}{*}{$\begin{array}{l}\text { Chi-square/ } \\
\text { p-value }\end{array}$} & \multicolumn{4}{|c|}{$\begin{array}{l}\text { Diabetes Mellitus, } \\
\text { N (row \%) }\end{array}$} & \multirow[t]{3}{*}{$\begin{array}{l}\text { Chi-square/ } \\
\text { p-value }\end{array}$} \\
\hline & \multicolumn{2}{|c|}{$\begin{array}{l}\text { HPN } \\
(n=108)\end{array}$} & \multicolumn{2}{|c|}{$\begin{array}{l}\text { Non-HPN } \\
(\mathrm{n}=222)\end{array}$} & & \multicolumn{2}{|c|}{$\begin{array}{l}\mathrm{HPC} \\
(n=140)\end{array}$} & \multicolumn{2}{|c|}{$\begin{array}{l}\text { Non-HPC } \\
(\mathrm{n}=190) \\
\end{array}$} & & \multicolumn{2}{|c|}{$\begin{array}{l}\mathrm{DM} \\
(\mathrm{n}=24)\end{array}$} & \multicolumn{2}{|c|}{$\begin{array}{r}\text { Non-DM } \\
(\mathrm{n}=306) \\
\end{array}$} & \\
\hline & $\mathrm{N}$ & $(\%)$ & $\mathrm{N}$ & $(\%)$ & & $\mathrm{N}$ & $(\%)$ & $\mathrm{N}$ & $(\%)$ & & $\mathrm{N}$ & $(\%)$ & $\mathrm{N}$ & $(\%)$ & \\
\hline Body Mass Index (BMI) & & & & & $29.426 /$ & & & & & $29.120 /$ & & & & & $20.015 /$ \\
\hline Underweight $\left(<18.5 \mathrm{~kg} / \mathrm{m}^{2}\right)$ & 2 & $(5.9)$ & 32 & $(94.1)$ & $<0.001$ & 6 & $(17.6)$ & 28 & $(82.4)$ & $<0.001$ & 0 & $(0.0)$ & 34 & $(100.0)$ & $<0.001$ \\
\hline Normal $\left(18.5-22.9 \mathrm{~kg} / \mathrm{m}^{2}\right)$ & 18 & (19.8) & 73 & $(80.2)$ & & 24 & $(26.4)$ & 67 & (73.6) & & 0 & $(0.0)$ & 91 & $(100.0)$ & \\
\hline Overweight $\left(23-27.4 \mathrm{~kg} / \mathrm{m}^{2}\right)$ & 39 & (38.6) & 62 & $(61.4)$ & & 52 & $(51.5)$ & 49 & $(48.5)$ & & 8 & $(7.9)$ & 93 & $(92.1)$ & \\
\hline Obese $\left(\geq 27.5 \mathrm{~kg} / \mathrm{m}^{2}\right)$ & 49 & $(47.1)$ & 55 & $(52.9)$ & & 58 & $(55.8)$ & 46 & $(44.2)$ & & 16 & $(15.4)$ & 88 & $(84.6)$ & \\
\hline Body Fat (BF) & & & & & $39.055 /<$ & & & & & $34.919 /$ & & & & & $21.404 /<$ \\
\hline Low BF & 1 & $(2.6)$ & 38 & $(97.4)$ & & 4 & $(10.3)$ & 35 & $(89.7)$ & $<0.001$ & 0 & $(0.0)$ & 39 & $(100.0)$ & \\
\hline Normal BF & 33 & (24.3) & 103 & $(75.7)$ & & 48 & (35.3) & 88 & $(64.7)$ & & 3 & $(2.2)$ & 133 & $(97.8)$ & \\
\hline Moderate BF & 49 & $(44.5)$ & 61 & $(55.5)$ & & 59 & $(53.6)$ & 51 & $(46.4)$ & & 13 & $(11.8)$ & 97 & $(88.2)$ & \\
\hline High BF & 25 & $(56.8)$ & 19 & $(43.2)$ & & 29 & $(65.9)$ & 15 & $(34.1)$ & & 8 & $(18.2)$ & 36 & $(81.8)$ & \\
\hline Waist Circumference (WC) & & & & & $22.936 /<$ & & & & & 25.991/ & & & & & $16.401 /<$ \\
\hline $\begin{array}{l}\text { Positive abdominal obesity } \\
\text { (Men: } \geq 90 \mathrm{~cm} \text {; Women: } \geq 80 \mathrm{~cm} \text { ) }\end{array}$ & 86 & $(42.6)$ & 116 & $(57.4)$ & & 108 & $(53.5)$ & 94 & $(46.5)$ & $<0.001$ & 24 & $(11.9)$ & 178 & $(88.1)$ & \\
\hline $\begin{array}{l}\text { Normal WC (Men: }<90 \mathrm{~cm} \text {; } \\
\text { Women: }<80 \mathrm{~cm} \text { ) }\end{array}$ & 22 & $(17.2)$ & 106 & $(82.8)$ & & 32 & (25.0) & 96 & (75.0) & & 0 & $(0.0)$ & 128 & $(100.0)$ & \\
\hline
\end{tabular}

unaware of their health problems. Over the period of intervention, those families became more empowered to access health services and community resources such as welfare payments, and there were reductions in blood pressure and blood glucose levels [43].

Semporna has two publicly funded health clinics where such health checks are available for a minimal payment, one on the Semporna mainland and the other on the largest island opposite the mainland. However access to health clinics for NCD detection in this rural coastal community might have been a challenge. There are also eight publicly funded community clinics which are located nearer to the communities that they serve. Unlike the health clinics, community clinics are staffed by community nurses whose focus are on maternal and child health, contraception, immunisation and child developmental assessments [15]. Another issue that required attention is the access to NCD prevention and promotion strategy in rural coastal communities in Sabah. The cost of access to health checks at private clinics is beyond the reach of most individuals in this rural coastal community as median per capita household income was RM83.33/month ( $\approx$ USD 20). Public funded NCD prevention and health promotions, whilst they were free, they did not reach those who may not have a need to visit health facilities or did not have access to health services [10]. The NCDP-1 M with its community partnering in NCD risk screening and health promotion were available in the rural coastal community in Semporna, but for various reasons, many adults had not accessed the free NCD risk screening. The high proportion of respondents in the present study who did not have a health check in the past 12 months could be due to a combination of access issues and lack of health awareness.

The situation in Semporna is unique compared to rural coastal communities in other parts of Malaysia and other Southeast Asian countries. Rural coastal communities in Sabah host settled people who might be of similar or different ethnic groups. In the present study, coastal Semporna, the islands off Semporna and its surrounding waters are also home to stateless Bajau Lauts who are of similar ethnicity and to a varying degree, similar culture with the citizen Bajaus. The stateless Bajau Lauts are mostly very poor and are habitually denied access to affordable health care services as Malaysian law does not distinguish the Bajau Lauts as undocumented inhabitants, from refugees and asylum seekers [14].

\section{Conclusions}

Many people in this rural coastal community were unaware that they had high cholesterol and elevated blood pressure. Their lack of health checks could either be attributable to limitations in access to affordable health services for NCD prevention and monitoring, or low health seeking behaviour, or both. Based on the findings, we suggest further studies in (1) the changes in food habits in a rural coastal community and their effects on NCD risks, (2) identifying risk factors for NCDs in rural 
coastal communities and, (3) the mechanisms for early detection of new cases and provision of adequate treatment. These studies should be conducted in both citizens and undocumented inhabitants who for all matters and purposes are settled within these rural communities.

\section{Abbreviations}

BMl: Body mass index; NCD: Non-communicable disease; NDCP-1 M: NCD Prevention 1 Malaysia; NHMS: National Health and Morbidity Survey; OR: Odd ratio; PLI: Poverty Line Income; RM: Ringgit Malaysia; WHO: World Health Organization

\section{Acknowledgements}

All authors would like to acknowledge the medical officer and nutritionist of Klinik Kesihatan Semporna (Semporna Health Clinic), village heads and participants for their support and cooperation throughout the data collection.

\section{Funding}

This research was funded by the Malaysian Government through the Ministry of Science, Technology and Innovation's Science Fund Research Project with the grant code 06-01-10SF0164. The funding body had no role in the design of the study or collection, analysis, and interpretation of data or in writing the manuscript. The authors also acknowledged the financial assistance for publication received from the Research University Grant awarded by the Ministry of Health to the National University of Malaysia specifically for the Consortium of B40 Research (CB40R) under the auspice of B40 Grand Challenges (IDE 2018-01).

\section{Availability of data and materials}

The datasets used and/or analysed during the current study are available from the corresponding author on reasonable request.

\section{About this supplement}

This article has been published as part of BMC Public Health Volume 19 Supplement 4, 2019: Health and Nutritional Issues Among Low Income Population in Malaysia. The full contents of the supplement are available online at https://bmcpublichealth.biomedcentral.com/articles/supplements/ volume-19-supplement-4.

\section{Authors' contributions}

$\mathrm{YBHO}, J S L$, and $\mathrm{PM}$ made contributions to the conception and design of this study. YBHO and JSL made substantial contribution to the study design and management of the research activities. $\mathrm{HH}$ interviewed all respondents with the aid of one paid enumerator. $\mathrm{YBHO}$ and $\mathrm{HH}$ drafted the manuscript and analysed the data. JSL and PM were involved in critical revision for important intellectual content. All authors have read and approved the final manuscript.

\section{Ethics approval and consent to participate}

Ethics approval was obtained from the Medical Research Ethics Committee, Faculty of Medicine and Health Sciences, Universiti Malaysia Sabah. The approval code is JKEtika 3/14(3). Written informed consent was obtained from all the participants.

\section{Consent for publication}

Not applicable.

\section{Competing interests}

The authors declare they have no competing interests.

\section{Publisher's Note}

Springer Nature remains neutral with regard to jurisdictional claims in published maps and institutional affiliations.
Published: 13 June 2019

\section{References}

1. Rampal L, Rampal S, Azhar MZ, Rahman AR. Prevalence, awareness, treatment and control of hypertension in Malaysia: a national study of 16,440 subjects. Public Health. 2008;122(1):11-8.

2. Narayan KA, A Rashid K. Blood pressure patterns and the prevalence of hypertension and its associated factors in a rural community in northern Malaysia. Malays J Public Health Med. 2007;7(1):14-9.

3. Tee SR, Teoh XY, Aiman WARWM, Aiful A, Har CSY, Tan ZF, et al. The prevalence of hypertension and its associated risk factors in two rural communities in Penang, Malaysia. Int E-J Sci Med Educ. 2010;4(2):27-40.

4. Institute for Public Health (IPH). Non-communicable diseases, risk factors \& other health problems. In: Volume II National Health and Morbidity Survey 2015 (NHMS 2015). 2015. Available from: http://iku.moh.gov.my/images/IKU/ Document/REPORT/nhmsreport2015vol2.pdf. Accessed 29 Oct 2018.

5. Abdul-Razak S, Daher AM, Ramli AS, Ariffin F, Mazapuspavina MY, Ambigga KS, et al. Prevalence, awareness, treatment, control and socio demography determinants of hypertension in Malaysian adults. BMC Public Health. 2016; 16(351).

6. Institute for Public Health (IPH). Summary of NHMS report on disease prevalence. In: National prevalence of noncommunicable diseases / risks factors from NHMS 1996 to 2015. 2017. Available from: http://iku.moh.gov.my/images/IKU/ Document/REPORT/nhmsreport2015vol2.pdf. Accessed 29 Oct 2018.

7. Institute for Public Health (IPH). Methodology and general findings. In: Voume 1 National Health and Morbidity Survey 2011 (NHMS 2011). 2011. Available from: http://iku.moh.gov.my/images/IKU/Document/REPORT/ NHMS2011-Volumel.pdf. Accessed 29 Oct 2018.

8. Institute for Public Health (IPH). Executive Summary. In: The Third National Health and Morbidity Survey (NHMS III) 2006. 2008. Available from: http:// iku.moh.gov.my/images/IKU/Document/REPORT/2006/ExecutiveSummary. pdf. Accessed 29 Oct 2018.

9. Institute for Public Health (IPH). Diabetes mellitus.In: The third National Health and Morbidity Survey 2006 (NHMS III). 2008. Available from: http:// iku.moh.gov.my/images/IKU/Document/REPORT/2006/DiabetesMellitus.pdf. Accessed 29 Oct 2018

10. Mustapha Fl, Omar ZA, Mihat O, Noh KM, Hassan N, Bakar RA, et al. Addressing non-communicable diseases in Malaysia: an integrative process of systems and community. BMC Public Health. 2014;14:54.

11. Liyanatul NZ, Nadiatul IZ, Wan MK, Noor HI, Intan SS, Hasneezah H, et al. The concept of district health management in Malaysia. Int J Public Health Clin Sci. 2016;3(1):1-6.

12. Wu F, Narimatsu H, Li X, Nakamura S, Sho R, Zhao G, et al. Non-communicable diseases control in China and Japan. Glob Health. 2017:13:19.

13. Department of Statistics Malaysia. Putrajaya: Department of Statistics Malaysia; 2010: p. 137

14. Acciaioli G, Brunt $\mathrm{H}$, Clifton J. Foreigners everywhere, nationals nowhere: exclusion, irregularity, and invisibility of stateless Bajau Laut in Eastern Sabah, Malaysia. J Immigr Refug Stud. 2017;15(3):232-49.

15. Ariff KM, Lieng TC. Rural health care in Malaysia. Aust J Rural Health. 2002; 10:99-103.

16. Chen X, Wei W, Zou S, Wu X, Zhou B, Fu L, et al. Trends in the prevalence of hypertension in island and coastal areas of China: a systematic review with meta-analysis. Am J Hypertens. 2014;27(12):1503-10.

17. Dollah R, Hassan WSW, Peters D, Othman Z. Old threats, new approach and national security in Malaysia: issues and challenges in dealing with crossborder crime in East Coast of Sabah. Mediterr J Soc Sci. 2016;7(3):178-86.

18. Ministry of Rural Development. Data asas Malaysia. Carta 8: Pendapatan garis kemiskinan (PGK) purata mengikut wilayah (Malaysia basic data. Chart 8: Average poverty line income (PLI) by region), 2014. Available from: http:// www.rurallink.gov.my/wp-content/uploads/2015/05/1-DATA-ASASMALAYSIA1.pdf. Accessed 30 Apr 2019.

19. Expert Consultation WHO. Appropriate body mass index for Asian populations and its implication for policy and intervention strategies. Lancet. 2004;363:157-63.

20. Gallagher D, Heymsfield SB, Heo M, Jebb SA, Murgatroyd PR, Sakamoto Y. Healthy percentage body fat ranges: an approach for developing guidelines based on body mass index. Am J Clin Nutr. 2000;72(3):697-701.

21. WHO/IOTF/IASO. The Asia Pacific perspective: redefining obesity and its treatment. 2000. Available from: http://www.wpro.who.int/nutrition/ documents/docs/Redefiningobesity.pdf. Accessed 29 Oct 2018. 
22. Ministry of Health Malaysia (MOH). Clinical practice guidelines. Management of hypertension. 5th ed. Putrajaya: Ministry of Health Malaysia; 2018. Available from http://www.moh.gov.my/moh/penerbitan/CPG/ MSH\%20Hypertension\%20CPG\%202018\%20V3.8\%20FA.pdf. Accessed 30 Apr 2019.

23. Ministry of Health Malaysia (MOH). Clinical practice guidelines. Management of type 2 diabetes mellitus. 5th ed. Putrajaya: Ministry of Health Malaysia; 2015. Available from: http://www.moh.gov.my/moh/resources/Penerbitan/ CPG/Endocrine/3a.pdf. Accessed 30 Apr 2019.

24. NIH. Third report of the National Cholesterol Education Program (NCEP) Expert Panel on detection, evaluation and treatment of high blood cholesterol in adults (adult treatment panel III): final report. Circulation. 2002;17(106):3143-421

25. Rampal S, Mahadeva S, Guallar E, Bulgiba A, Mohamed R, Rahmat R, et al. Ethnic differences in the prevalence of metabolic syndrome: results from a multi-ethnic population-based survey in Malaysia. PLoS One. 2012;7(9):e46365.

26. Schagatay E, Abrahamsson E. A living based on breath-hold diving in the Bajau Laut. Hum Evol. 2014;29(1-3):171-83.

27. Ilardo MA, Moltke I, Korneliussen TS, Cheng J, Stern AJ, Racimo F, et al. Physiological and genetic adaptations to diving in sea nomads. Cell. 2018; 173:569-80.

28. Ley EJ, Singer MB, Clond MA, Johnson T, Bukur M, Chung R, et al. Longterm effect of trauma splenectomy on blood glucose. J Surg Res. 2012;177: $152-6$.

29. Mohd Yunus AS, Sherina MS, Nor Afiah MZ, Rampal L, Tiew KH. Prevalence of cardiovascular risk factors in a rural community in Mukim Dengkil, Selangor. Malays J Nutr. 2004;10(1):5-11.

30. Masud MM, Kari F, Yahaya SRB, Al-Amin AQ. Livelihood assets and vulnerability context of marine park community development in Malaysia. Soc Indic Res. 2016;125:771-92.

31. Taylor R, Badcock J, King H, Pargeter K, Zimmet P, Fred T, et al. Dietary intake, exercise, obesity and noncommunicale disease in rural and urban populations of three Pacific island countries. J Am Coll Nutr. 1992;11(3):283-93.

32. Dancause KN, Dehuff C, Soloway LE, Vilar M, Chan C, Wilson M, et al. Behavioural changes associated with economic development in the South Pacific: health transition in Vanuatu. Am J Hum Biol. 2011;23:366-76.

33. Yang J, Lu F, Zhang C, Liu Z, Zhao Y, Gao F, et al. Prevalence of prehypertension and hypertension in a Chinese rural area from 1991 to 2007. Hypertens Res. 2010;33:331-7.

34. Narayan KA, Khan AR. Body mass index and nutritional status of adults in two rural villages in northern Malaysia. Malays J Nutr. 2007;13(1):9-17.

35. Yoon KH, Lee JH, Kim JW, Cho JH, Choi YH, Ko SH, et al. Epidemic obesity and type 2 diabetes in Asia. Lancet. 2006;368:1681-8.

36. Adair LS, Kuzawa C, McDade T, Carba DB, Borja JB. Seventeen-year changes in body mass index, waist circumference, elevated blood pressure, and diabetes phenotypes in a cohort of Filipino women. Asia Pac J Public Health. 2018;30(6):567-71.

37. Hardiman SL, Bernanthus IN, Rustati PK, Susiyanti E. Waist circumference as a predictor for blood glucose levels in adults. Universa Medicina. 2009;(28): 77-82.

38. Annadurai K, Balan N, Ranaganathan K. Non-communicable disease risk factor profile among fishermen community of Kancheepuram district, Tamil Nadu: a cross sectional study. Int J Community Med Public Health. 2018;5: 708-13.

39. Kini S, Kamath VG, Kulkarni MM, Kamath A, Shivalli S. Pre-hypertension among young adults (20 - 30 years) in coastal villages of Udupi District in Southern India: an alarming scenario. PLoS One. 2016;11:e0154538.

40. Institute for Public Health (IPH): National Health and Morbidity Survey 2014: Malaysian Adult Nutrition Survey (MANS) In., vol. II: Survey Findings; 2014 : 343.

41. Li J, Shi L, Li S, Xu L, Qin W, Wang H. Urban-rural disparities in hypertension prevalence, detection, and medication use among Chinese adults from 1993 to 2011. Int J Equity Health. 2017;16:50.

42. Gan CY, Chan MKC. A blood pressure profile of rural Kadazans and Bajaus in Sabah, East Malaysia. Southeast Asian J Trop Med Public Health. 1993;24(3): 583-9.

43. Faris A, Robinson F, Tha NO, Shoesmith W, Ali O, Naing DKS. PuPUK: a community engaged medical curriculum by the School of Medicine, Universiti Malaysia Sabah. Int J Collab Res Intern Med Public Health. 2013; 5(1):79-88.

\section{Ready to submit your research? Choose BMC and benefit from:}

- fast, convenient online submission

- thorough peer review by experienced researchers in your field

- rapid publication on acceptance

- support for research data, including large and complex data types

- gold Open Access which fosters wider collaboration and increased citations

- maximum visibility for your research: over $100 \mathrm{M}$ website views per year

At BMC, research is always in progress.

Learn more biomedcentral.com/submissions 